\title{
World Natural Heritage: its Purpose and Significance
}

\author{
Leslie F. Molloy Member, IUCN Commission on National Parks and Protected Areas; Co-ordinator, \\ Heritage Interpretation, New Zealand Department of Conservation
}

\begin{abstract}
The refinement of IUCN thinking on the selection and protection of World Natural Heritage is outlined. The Yakushima World Heritage site is evaluated in terms of the extent to which it meets the new criteria. The future management of Yakushima World Heritage Area (WHA) site (and its buffering forests) is discussed and the criteria are considered in relation to the selection of other World Heritage sites in the humid evergreen forest ecosystems of the world.

Four sets of principles are advanced to help guide the future management of visitors to Yakushima WHA in order to:

- protect the natural values of the site

- foster (enjoyable) visits by the public

- manage tourism (through regulation)

- inform and educate visitors (on the conservation values of the site).

Finally, the paper encourages the development of an effective partnership between the management agencies and the Yaku people in the future management of the World Heritage site.
\end{abstract}

Key Words: World Natural Heritage / Yakushima WHA / criteria for selection / 'outstanding universal value / natural beauty / natural site / site integrity / visitor management strategy / working with local communities.

In May 1993 I was lucky enough to be one of the 2-person IUCN team which visited Kagoshima and Yakushima Island, to evaluate the Japanese government's nomination of around 10,000 hectares of the mountainous interior of Yakushima Island for World Heritage status. During the course of a week, Dr Jim Thorsell and myself were able to discuss Yakushima's values with government and prefecture officials, and scientists and the inhabitants of Yakushima Island. Fortunately, most of the time was spent on the island, including a traverse on foot of the summit, Miyanoura-dake, and the high altitude cloud forest, with its impressive Yakusugi.

The World Heritage Committee of UNESCO considered our report, and the information of other experts, and inscribed Yakushima on the list of World Natural Heritage sites. Yet, that decision was just the beginning of an exciting journey to grant greater protection to the forest ecosystems of Yakushima, and develop a co-ordinated management regime which recognizes the needs of visitors and the inhabitants of Yakushima, and seeks their involvement in sustaining the natural values of the island for future generations.

Thank you for your invitation to address this symposium on the purpose and significance of World Natural Heritage. The views expressed in my paper are my own, as a member of IUCN's Commission on National Parks and Protected Areas; they are not necessarily the official views of IUCN, or the opinions of the New Zealand Department of Conservation which employs me.

It is my hope that my presentation will provide you, as forest ecosystem scientists and resource managers, with sufficient background on the meaning of World Natural Heritage status, to assist you in your symposium deliberations. In particular, I want to comment on: 
- current IUCN thinking on the criteria for World Natural Heritage

- the views of the evaluation team on future management needs of Yakushima World Heritage site

- some pertinent nature conservation comments from the OECD Environmental Review of Japan

- the management of visitor impacts (including some comparisons with forested sites in New Zealand)

- ways of working with the Yakushima people and the tourism industry.

\section{THE WORLD HERITAGE CONVENTION AND WORLD NATURAL HERITAGE}

The aim of the World Heritage Convention (1972), put simply, is that the list of World Heritage sites should contain the best examples of the world's cultural and natural heritage; their protection, in a sense, is the responsibility of all humanity, for their loss would impoverish us all.

To be inscribed on the list, the nominated property must be demonstrated to be of "outstanding universal value". This is a rigorous test, for the list is not intended to cover all properties of national (or international) interest or importance; rather, the property must be nothing short of outstanding value in the international context. It follows, therefore, that not all nominated properties are automatically inscribed - of the 122 natural heritage sites evaluated in the 1984 - 1994 period, only 73 were directly inscribed.

It is often said that the World Heritage Convention is one of the most respected of international conventions; as of 31 March 1996, 146 countries are signatories to the Convention. As of December 1995, the World Heritage List contained 469 sites, 350 or which are cultural properties, 102 natural properties, and 17 of mixed natural/cultural character in their outstanding universal value.

With respect to natural properties, inclusion on the list is determined by four criteria, as well as meeting conditions of integrity. Over the last 24 years the criteria have been refined, with the current criteria (listed, along with integrity conditions, in Appendix 1) differing slightly from those used in 1993 when Yakushima was inscribed. However, the new criteria essentially concentrate on the same natural issues (of outstanding universal value), namely:

(i) geological processes (including evolution of the earth)

(ii) on-going ecological and biological processes

(iii) superlative natural phenomena and/or areas of exceptional natural beauty

(iv) habitats for the conservation of biological diversity (including threatened species).

Yakushima Island site was inscribed on the basis of criteria (ii) and (iii).

A large part of the Yakushima World Natural Heritage site is also a Biosphere Reserve - one of a proposed network of such reserves throughout East Asia and the Pacific region, the establishment of which is one of the two objectives of this symposium. As you are all aware, Biosphere Reserves are a concept which emerged from UNESCO's Man in the Biosphere Programme (MAB), which predates the World Heritage Convention. There are currently about 328 Biosphere Reserves in 82 countries and it is timely for me to reiterate the essential differences between the two protection mechanisms. While a World Heritage site can be like the strictly-protected 'core' of a Biosphere Reserve (surrounded by a 'buffer' zone where controlled, non-destructive uses are permitted), each has different rationales and objectives. Primarily, Biosphere Reserves are intended to be part of an international (and regional) network of reserves where the focus is on research to determine how conservation and human use can be integrated (or balanced), often through the use of environmentally-sensitive management techniques. World Heritage Areas, instead, have the simpler objective of protecting and conserving for future generations - the world's most outstanding places. 


\section{CURRENT IUCN THINKING ON SELECTION AND PROTECTION OF WORLD NATURAL HERITAGE}

With the approaching 25th anniversary of the establishment of the World Heritage Convention, IUCN has invited its commission members to share their ideas about how well the convention is working with regard to the protection of natural 'World Heritage' sites. Many of these ideas were synthesised at a meeting at Parc National de la Vanoise, in France, in March of this year. I have attempted to summarise below the conclusions of this meeting because I believe that they have a bearing upon how we could approach the future management of the Yakushima site (and its buffering forests) and the selection of other World Heritage (and perhaps Biosphere Reserve) sites in the humid evergreen forest ecosystems of the world.

(a) How should "outstanding universal value" be interpreted?

IUCN conclusions:

the intention is to not list all sites of great interest, importance or value

$\bigcirc$ although sites would be the "best of their kind", a regional perspective is also required in order to make a selection

$\bigcirc$ the term implies uniqueness and representatives, so the comparative evaluation of similar properties is essential.

Relevance to Yakushima WHA:

The World Heritage Committee accepted that Yakushima qualified on criterion (ii), particularly because of the altitudinal distribution of vegetation, from sea level to almost $2000 \mathrm{~m}$. The site had elements of uniqueness and representatives - on one small island there was an unbroken forest sequence from subtropical coastal forest, through warm-temperate montane evergreen forest, to cooltemperate coniferous cloud forest. Three other island World Heritage sites - SW Tasmania, Scandola in Corsica and Garajonay in the Canaries - had vegetation gradients that extended from sea level to mountain summits. Yakushima, however, had significant floristic diversity, partly related to its location at the border of the palearctic and oriental biogeographic region.

In terms of the scientific importance of the ancient Japanese cedar forests in Yakushina, there were similarities with three other, much larger, North American World Heritage sites - Olympic, Yosemite and Redwoods. Yet, IUCN was unable to undertake a rigorous comparative evaluation of similar ecosystems in East Asia - the conclusions had to be based on the best information available.

(b) How should "natural beauty" (criterion (iii)) be evaluated?

IUCN conclusion:

This is a very subjective, culturally-influenced, criterion. Although the universal importance of aesthetics is appreciated, it is recommended that, in future, criterion (iii) is generally insufficient on its own. It should only justify inclusion of a site on the list when used in conjunction with other criteria.

Relevance to Yakushima WHA:

There was no doubt in the minds of the evaluating team that the Yakushima site was a place of "superlative natural phenomena" (Yakusugi) and "exceptional natural beauty" (wild, mountain summits with spectacular granite monoliths; steep forested topography, with gorges and waterfalls; gnarled, ancient trees). 
(c) What, exactly, is a "natural" site?

IUCN conclusion:

Globally, pristine nature is now a very narrow concept, probably restricted to a very few isolated oceanic islands. Virtually all World Heritage sites lie along a continuum, from nature to culture. Consequently, the World Heritage Committee has been asked to consider whether it is possible to develop one set of criteria for both natural and cultural sites.

Relevance to Yakushima WHA:

The Yakushima site has very high cultural significance to the Japanese people. Although only nominated as a natural site, the mountains of Yakushima have always been held in awe by the Yaku people because of their spiritual significance, and the Yakusugi were traditionally revered as a dwelling of kami, overwhelming mortal senses by their size, longevity and strength.

\section{(d) How should the requirement for 'integrity' be clarified?}

\section{IUCN conclusion:}

The concept of site integrity (see Appendix 1) is interpreted widely - and sometimes ignored. There are different notions of integrity - structural, functional, or visual. Again, there is much to commend the World Heritage Committee attempting to devise a common integrity approach for both natural and cultural sites.

Relevance to Yakushima WHA:

The deficiencies in functional and visual integrity of the Yakushima site were pointed out during the IUCN evaluation. The complex sinuous boundary (less than $1 \mathrm{~km}$ wide in places) would require some eventual "in-filling" and careful management of the adjacent buffer areas. The administrative compartmentalisation of the site, with overlapping protected areas under different pieces of legislation, was of some concern; but perhaps that is the Japanese way? The lack of any formal structure, and management plan for the entire site (especially the likely impact of visitors along the Okabu trail and in the vicinity of Jomon-sugi and Wilson stump), were also integrity concerns. However, the World Heritage Committee were assured by Japanese authorities that these integrity issues would be addressed through a Management Committee once the site was inscribed.

\section{(e) How can a better global coverage of natural sites be achieved?}

The IUCN objective is to fill the gaps by adding to the 102 natural sites on the list, without losing the international credibility of the list through an unreasonable number of new inscriptions. The dual approach is to (i) have member countries submit tentative national lists, and (ii) develop global thematic lists or frameworks (eg, fossil sites, islands, mountains, etc.).

Along with the organisers of the symposium, I would be delighted if this meeting gave us a clearer picture of gaps in the coverage of sites of "outstanding universal value" in the humid evergreen forest ecosystems of the northern hemisphere.

\section{(f) Better management of World Natural Heritage sites}

IUCN believes that there is an urgent need to put more effort into the management of sites on the list, and perhaps less effort into selection of more sites (except for those biomes where listed sites are clearly lacking). There is particular concern for those sites on the "World Heritage in Danger" list.

Better international co-operation is going to be essential to ensure that this global heritage is really protected. We CAN learn from each other. We need to strengthen the links between management and scientists; between national legislators and members of international conservation networks like 
IUCN; and between the indigenous or local people and World Heritage site managers.

\section{JAPAN AND NATURE CONSERVATION}

In April 1993, I was invited to Japan on another conservation assignment - this time as a member of the OECD's international team reviewing the state of Japan's environment. It is arrogant in the extreme to consider that a group of westerners, no matter how knowledgeable, can in the space of a few weeks come to a considered view on a country as complex and populous as Japan. Nevertheless, we had to do our best, and in that humble spirit, I would like to share some of our conclusions, as they pertain to nature conservation in Japan - and Yakushima.

The OECD report observed that over the last 20 to 30 years, wild nature in Japan had retreated (and is still retreating further) into the mountainous interior and the outer islands. Japan seemed to be at a cross-roads, having to make a conscious decision to strive for significant gains in nature conservation, or experience irreversible losses. The two key nature conservation issues were:

$\bigcirc$ the need to close the gap between sound policy objectives, and indifferent policy results; and

harmonise newer, more-consumptive urban lifestyles with traditional and environmental values.

The OECD report made a number of recommendations, some of which seem to be pertinent to the Yakushima situation.

the preparation of a comprehensive Nature Conservation Strategy for Japan.

$\bigcirc$ setting a goal of ultimately protecting $1 \%$ of the country as strictly protected nature conservation reserves, representative of the main ecosystems.

$\checkmark$ the development of better planning frameworks for protected areas, based on the principle of sustaining the natural resources in these areas, and involving local government, conservation NGO's, and the public.

increasing the level of technical and managerial staffing of protected areas from current woefully low levels.

$\bigcirc$ the wider use of economic instruments to redress the management burden caused by the increasing impacts of visitors and the tourism industry.

In essence, the OECD concluded that the continued heavy pressure of economic growth and urbanisation on the natural environment is not an insoluble problem for a country as advanced and innovative as Japan. What seemed to be lacking, however, was sufficient public awareness of the incremental loss of wild nature, and the political will to regulate a wide range of uses and interests currently working against nature conservation.

\section{MANAGEMENT OF VISITOR TO YAKUSHIMA WHA}

It is probably fair to say that most World Heritage sites were already popular destinations for visitors prior to being inscribed on the list. World Heritage status vastly increases the international profile of the site, and, as a consequence, the procession of visitors - whether committed, collectors, or just curious. This is particularly of concern with a relatively undeveloped, rugged, high rainfall site like Yakushima.

Because the site has only a rudimentary infrastructure for handling visitors, management authorities are faced with a dilemma - to discourage large-scale visitation by keeping facilities to a minimum, or to upgrade facilities in anticipation of the visitor influx. 
My advice on this critical issue is coloured by our experience in World Heritage site management in New Zealand. Although New Zealand faces only a minute proportion of the domestic visitor pressure that Japan has on its special heritage sites, the pressure of overseas visitors is increasing rapidly. Already annual overseas visitor numbers are equivalent to one third of the New Zealand population - with Japanese making up $17 \%$ of overseas visitors coming for a holiday. There are also many physical similarities between Japan and New Zealand. Both are of similar size, each a collection of islands subject to severe environmental conditions - extremes of climate, volcanism and tectonic activity (especially earthquakes). Both are very mountainous with forests covering most of the erosion-prone steeplands.

For the past 2 years we have undertaken wide public consultation in the development of a Visitor Strategy(1) for the protected landscapes of New Zealand (about 30\% of the country). The following suggestions on visitors and site management are drawn from that Visitor Strategy, as well as from a recently published important IUCN document, "Tourism, ecotourism and protected areas", the outcome of the tourism workshops at the 1992 Venezuela Congress on National Parks and Protected Areas(2).

The fundamental planning step is the preparation of a Visitor Management Strategy for the Yakushima site. Ideally, such a strategy would be part of a tourism strategy for the whole island. The strategy should involve the four main "stakeholders":

the prefecture and local government

the world heritage site managers (and public conservation groups)

$\bigcirc$ the affected local communities

the tourism industry.

The strategy should assess the current visitor situation, evaluate what types of recreational opportunities and educational experiences the site offers, and decide what sort of tourism the site managers and local people want.

A site Visitor Management Plan should then be developed, sufficiently prescriptive to enable management to monitor the impacts of visitors against acceptable levels. The success, or otherwise, of the Visitor Management Plan depends upon how well it understands the needs of the different parties the biophysical requirements of the site, the desires of the visitors for certain experiences, the expectations of the local people for economic security, etc. Fundamentally, this requires a lot of good will, building relationships between site managers, visitors, tourism operators, local service providers - and eventually evolving into a sophisticated partnership between all parties. However, there is no way that everybody's unfettered expectations can be met; there have to be underlying principles which ensure that the value of the World Heritage site is sustained in perpetuity.

In New Zealand's two World Heritage sites - Te Wahipounamu (2.6 million hectares) and Tongariro (79,000 hectares) - we have applied four sets of such principles to assist us, as managers, to strike this sustainable balance:

\section{(a) Principles for Protecting the Natural Values of the Site}

the protection of natural values is more important than the provision of visitor facilities or services.

it is best to retain most areas in a natural state, without visitor facilities.

deny (or severely restrict) access to vulnerable parts of the site.

$\bigcirc$ safeguard, solitude, peace, and natural quiet 
ensure that facilities and services are appropriately located and well designed.

$\bigcirc$ give preference to visitor activities that promote increased understanding of natural values

encourage visitors to minimise their own impacts on the site environment.

This set of principles are the most important, for the ultimate protection of the site depends upon them. Measuring the environmental impacts of visitors, and devising effective management responses, is essential if these principles are to be followed.

\section{(b) Principles for Fostering Visits by the Public}

Visitors are entitled to experience inspiration, enjoyment and recreational opportunities provided by global heritage.

Management should attempt to provide a range of recreational opportunities (from developed sites to wilderness areas).

$\bigcirc$ Access should generally be free (but may be controlled, to protect vulnerable environments or visitor safety).

Visitors are entitled to solitude, peace and natural quiet.

Visitors are encouraged to avoid conflicts with other visitors.

Basic visitor facilities should be provided where appropriate.

While the needs of visitors should be subservient to the need to protect the site effectively, the visitor, nevertheless, should have a enjoyable and stimulating experience. Not all visitors are the same - they differ widely in cultural background, survival skills, knowledge, gender, age, etc. In our experience, management needs to understand the needs of potential visitor groups, encouraging those groups which are in harmony with the protection principles outlined in (a). It is worth stressing the point - not all categories of visitors need to be catered for in a World Heritage Area. What type of visitors do the local inhabitants want? What are the recreational and educational preferences of these types of visitors? Can they be catered for in different "use zones"?

Decisions on the provision of visitor facilities and services should flow from the above analysis whether roads, visitor centers, tracks, huts, bridges, boardwalks, viewing platforms, interpretation panels, etc are needed. As a general rule, we have insisted that virtually all roadside overnight accommodation (except some camping areas) should lie outside the World Heritage Area - in urban service centers. The only accommodation is in the form of backcountry huts, which require fitness and backcountry skills to reach.

\section{(c) Principles For Managing Tourism}

The tourism industry can play an important role for visitors.

Tourism must be carefully regulated through concessions.

Tourism activities and services must always be in keeping with natural values.

Tourism must be carefully managed, to avoid compromising experiences of other visitors.

Generally tourism should not be granted any widespread exclusive rights, especially any restriction of public access.

Discussion of how best to manage the tourism industry in World Heritage Areas could fill a full symposium - and has filled many books. The industry plays an important visitor service role in New Zealand's two World Heritage Areas. However, in every case it is carefully controlled through a concession; their impacts are monitored, and there are several instances of concessions not being 
renewed because of the company's inability to meet the required standards.

I do not want to develop further the principles outlined above, except to say that we believe that no responsible World Heritage agency can take a laissez faire attitude toward tourism; rather, the industry needs careful regulation - for its own good and the good of all visitors, and the health of the site. I commend to you, again, the wealth of information and guidelines in the IUCN book "Tourism, Ecotourism, and Protected Areas". (2).

\section{(d) Principles For Informing And Educating Visitors}

$\bigcirc$ Visitors are entitled to increase their knowledge of natural heritage.

Oncreasing visitor awareness of natural heritage values can lead to respect and concern for conservation.

Indigenous people should be encouraged to interpret their natural heritage in ways they consider appropriate.

Information and interpretation services should be accurate and of a high standard.

A range of effective and culturally-appropriate media should be used in communicating with visitors.

Visitors are entitled to objective information about risks to their safety.

Article 27 of the Convention calls for all signatory countries to strengthen appreciation and respect for natural and cultural heritage in their care through educational and information programmes. Worldwide, the increasing breadth and depth of heritage information and interpretation provided at sites is very impressive. In most cases, the "information gateway" is via visitor centers at key locations, or specialist interpretive centers - like the impressive Yakusugi Museum. On-site interpretation (either by panels, or guided walks) at accessible 'window' sites, like "Yakusugi-Land", is also an effective technique for achieving this goal, as well as reducing visitor pressure on the more remote, or fragile, parts of the World Heritage site itself.

\section{WORKING WITH YAKUSHIMA'S LOCAL COMMUNITIES}

In conclusion, I want to return to the 'co-existence' theme in the title of this symposium. The Yaku people have clearly co-existed with, indeed sustained, the forests of Yakushima Island for centuries. But how will they co-exist with the designated World Heritage site? Is this 'co-existence' a kind of sufferance, or will it be a partnership which will bring benefits to both the forests and the people?

Again, I cannot speak with authority on the current situation in Yakushima - we will all learn more of this relationship during our field visits. However, I do have real experience of how the attitudes of the local communities in the South West land sector of New Zealand's vast Te Wahipounamu World Heritage Area changed with time. The initial skepticism and hostility was turned around by the government management authorities (the Department of Conservation) by involving them closely in the subsequent planning and development of visitor facilities and services. The local people became a key ingredient in decision-making. This change in attitude did not occur until these remote communities perceived that the natural environment was worth conserving, that well-managed "ecotourism" services to selected visitors could sustain, in fact improve, their quality of life, and that they needed to swallow their pride and be willing to share their forests with visitors (even foregoing some of their traditional economic activities, such as forest logging).

This relationship between 'visitor' and 'host' needs to be based on an affirmation of the dignity of each party. The principles underlying such a relationship are both ecological and ethical. In closing, I 
can provide no better insight into this potentially-vexacious issue, than to again quote from the IUCN ecotourism publication (2), paraphrasing seven wise points made by George Wallace in a paper to the 1992 National Park and Protected Areas Congress in Venezuela. Wallace believes that 'ecotourism' should:

view natural areas both as "home to all of us" in a global sense but "home to nearby residents" specifically

minimise negative impacts on the environment and local people

$\bigcirc$ contribute to the better management of protected areas and to relationships between local people and those managing protected areas

$\bigcirc$ direct economic and other benefits to local people and maximise their participation in the decision-making process that determines the kind and amount of tourism that is to occur

$\bigcirc$ promote authentic two-way interaction between hosts and visitors, as well as an interest in sustainable development and wildland protection in both the host and the home country

$\bigcirc$ supplement or complement traditional practices (farming, fishing, social systems, etc.) without overwhelming or attempting to replace them, and make the local economy more robust and less susceptible to rapid change or world economic downturns

$\bigcirc$ provide special opportunities for local people or nature tourism employees to utilize natural areas and learn more about the sites that other visitors come to see.

\section{REFERENCES}

(1) New Zealand Department of Conservation, 1996. Visitor Strategy. Department of Conservation, Wellington. $60 \mathrm{pp}$.

(2) Ceballes - Lascurain, H., 1996. Tourism, Ecotourism and Protected Areas: The State of Naturebased Tourism Around the World and Guidelines for its Development. IUCN, Glaud, Switzerland and Cambridge, UK. 301 pp.

\section{F. MOLLOY 世界自然遺産，その目的と意義}

世界自然遺産野選択と保護について国際自然保護連合の考え方を概述した。屋久島世界遺産地域は新 しい基準を満たしていることで評価されている。屋久島世界自然遺産地域の将来の管理については, その緩衝地域を含めて検討され，その基準は，世界中の常緑湿潤林生態系における他の世界遺産地域 との選択のなかで考えられた。屋久島世界遺産地域を訪れる観光客を将来どのようにして誘導するか について四つの原則を考えたい。即ち, 遺産地域の自然の価值を護ること, 楽しい入域を促進する, （制限を加えて）観光を管理する，地域の保護価値について入域者に情報を与え，教育することの 4 点である。

最後に本論文が, 屋久島自然遺産地域の将来について，管理に当る省庁と屋久島の住民との協力関 係を築く契機となれば幸いである。 
APPENDIX 1

\begin{tabular}{|c|c|}
\hline \multicolumn{2}{|c|}{ NATURAL HERITAGE CRITERIA AND } \\
\hline (i) & $\begin{array}{l}\text { Criteria } \\
\text { be outstanding examples representing major stages } \\
\text { of earth's history, including the record of life, } \\
\text { significant on-going geological processes in the } \\
\text { development of landforms, or significant } \\
\text { geomorphic or physiographic features; }\end{array}$ \\
\hline
\end{tabular}

(ii) be outstanding examples representing significant ongoing ecological and biological processes in the evolution and development of terrestrial, fresh water, coastal and marine ecosystems and communities of plants and animals should contain all or most of the key interrelated and interdependent elements in their natural relationships; for example, an 'ice age' area would be expected to include the snow field, the glacier itself and samples of cutting patterns, deposition and colonisation (striations, moraines, pioneer stages of plant succession etc); in the case of volcanoes, the magmatic series should be complete and all or most of the varieties of effusive rocks and types of eruptions be represented.

should have sufficient size and contain the necessary elements to demonstrate the key aspects of processes that are essential for the long-term conservation of the ecosystems and biological diversity they contain; for example, an area of tropical rain forest should include a certain amount of variation in elevation above sea-level, changes in topography and soil types, patch systems and naturally regenerating patches; similarly a coral reef should include, for example, seagrass, mangroves or other adjacent ecosystems that regulate nutrient and sediment inputs into the reef.

(iii) contain superlative natural phenomena or areas of exceptional natural beauty and aesthetic importance

should be of outstanding aesthetic value and include areas that are essential for maintaining the beauty of the site; for example, a site whose scenic values depend on a waterfall, should include adjacent catchment and downstream areas that are integrally linked to the maintenance of the aesthetic qualities of the site.

(iv) contain the most important and significant natural habitats for in-situ conservation of biological diversity, including those containing threatened species of outstanding universal value from the point of view of science or conservation should contain habitats for maintaining the most diverse fauna and flora characteristic of the biographic province and ecosystem under consideration; for example, a tropical savannah should include a complete assemblage of co-evolved herbivores and plants; an island ecosystem should include habitats for maintaining endemic biota; a site containing wide-ranging species should be large enough to include the most critical habitats essential to ensure the populations of those species; for an area containing migratory species, seasonal breeding and nesting sites, and migratory routes, wherever they are located, should be adequately protected; international conventions, eg. the Convention of Wetlands of International Importance Especially as Waterfowl Habitat (Ramsar Convention), for ensuring the protection of habitats of migratory species of waterfowl, and other multi- and bilateral agreements could provide this assurance. 